
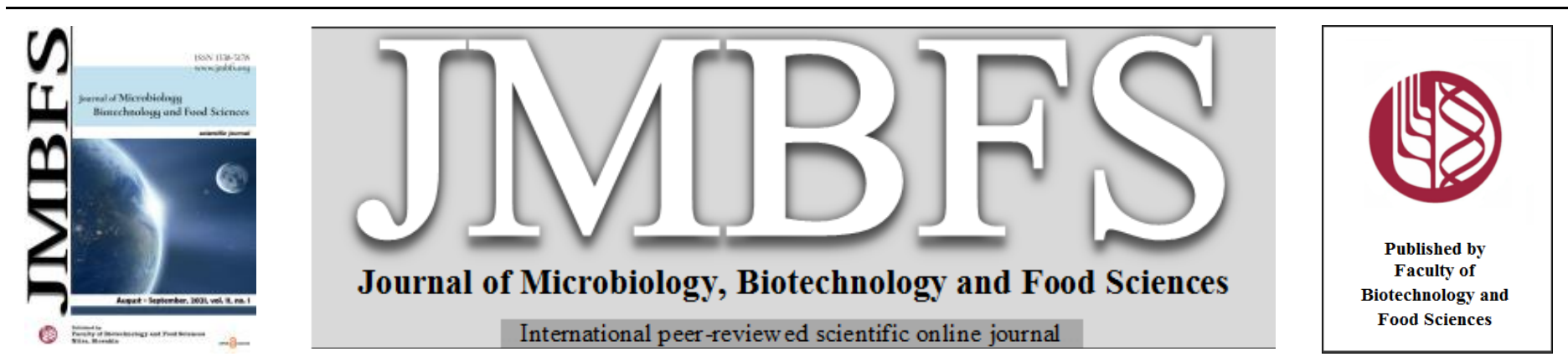

\title{
EFFECT OF ZEOLITE (CLINOPTILOLITE) ON CHEMICAL PARAMETERS OF RABBIT MEAT
}

\author{
Peter Herc ${ }^{1}$, Ondřej Bučko ${ }^{2}$, Filip Tirpák ${ }^{3}$, Katarína Tokárová ${ }^{4}$, Francesco Vizzarri $^{5}$, Peter Massányi ${ }^{4}$, Tomáš Slanina $^{* 4}$
}

\author{
Address(es): Ing. Tomáš Slanina, $\mathrm{PhD}$. \\ ${ }^{1}$ Slovak University of Agriculture in Nitra, Faculty of Biotechnology and Food Science, Department of Technology and Quality of Animal Products, Tr. A. Hlinku 2, \\ 94976 Nitra, Slovakia. \\ ${ }^{2}$ Slovak University of Agriculture in Nitra, Faculty of Agrobiology and Food Resources, Department of Special Animal Breeding, Tr. A. Hlinku 2,94976 Nitra, \\ Slovakia. \\ ${ }^{3}$ AgroBioTech Research Centre, Slovak University of Agriculture in Nitra, Tr. A. Hlinku 2, 94976 Nitra, Slovakia. \\ ${ }^{4}$ Slovak University of Agriculture in Nitra, Faculty of Biotechnology and Food Sciences, Department of Animal Physiology, Tr. A. Hlinku 2, 94976 Nitra, Slovakia. \\ ${ }^{5}$ University of Bari Aldo Moro. Department of Agricultural and Environmental Science, Via G. Amendola 165/A, 70126 Bari, Italy.
}

*Corresponding author: tomas.slanina@uniag.sk

https://doi.org/10.15414/jmbfs.3986

\section{ARTICLE INFO}

Received 20.11.2020

Revised 4. 3. 2021

Accepted 24. 3. 2021

Published 1. 8. 2021

Regular article OPEN $\partial_{\text {ACCESS }}$

\begin{abstract}
This work is aimed to evaluate the effect of natural zeolite on selected parameters of the rabbit's meat chemical composition. The rabbits of the Castorex breed $(n=12)$ were divided into two groups: Control group $C(n=6)$ without the addition of zeolite in feed and the experimental group $\mathrm{Z}(\mathrm{n}=6)$ in which animals received zeolite daily in a peroral form in concentration $0.2 \mathrm{~g} / \mathrm{kg}$ of body weight. Determination of the nutritional composition of rabbit meat and analysis of individual amino acids and fatty acids was performed by the Nicolet 6700 using FT-IR method (fourier transform infrared spectroscopy) in the musculus Longissimus dorsi (MLD) and the musculus Vastus lateralis (MVL). The content of water in meat in group Z $(73.630 \pm 0.270 \mathrm{~g} * 100 \mathrm{~g}-1)$ was significantly higher $(\mathrm{P} \leq 0.05)$ compared to group C $(72.480 \pm 0.530 \mathrm{~g} * 100 \mathrm{~g}-1)$. Cysteine content in MLD in group Z $(0.289 \pm 0.007 \mathrm{~g} * 100 \mathrm{~g}-1)$ was significantly (P $\leq 0.05)$ higher than in group $\mathrm{C}(0.277 \pm 0.011 \mathrm{~g} * 100 \mathrm{~g}-1)$. Another noticeable difference in the statistical level $\mathrm{p} \leq 0.05$ in favor of zeolite was found in linoleic acid content in MLD with mean values in group Z $(0.324 \pm 0.016 \mathrm{~g} * 100 \mathrm{~g}-1 \mathrm{FAME})$ against the group C $(0.293 \pm 0.009 \mathrm{~g} * 100 \mathrm{~g}-1$ FAME). Therefore, the addition of zeolite to the rabbit feeding diet possibly increases the proportion of essential linoleic fatty acid and thereby may improve the nutritional value of the meat. Increased cysteine value can lead to a better degradation of heavy metals in meat.
\end{abstract}

Keywords: clinoptilolite, feed, rabbit, meat, chemical composition

\section{INTRODUCTION}

Meat from rabbit is highly digestible, tasty, low-calorie and often recommended by nutritionists over other meat types. The leanest cut of meat in the rabbit carcass is the loin. The quantitatively most important cut is the hind leg, with a moderate lipid content compared with most types of meat consumed nowadays. Lipid content depends on the productive factors, especially diet (Dalle Zotte, 2002). Rabbit meat is characterized by a low proportion of intramuscular fat and a high proportion of protein. Furthermore, rabbit meat is also an important source of highly available micronutrients, such as vitamins and minerals. Likewise, rabbit meat does not contain uric acid and has a low content of purines (Hernández, 2007). Rabbit meat is rich in unsaturated and polyunsaturated fatty acids that are important in terms of human nutrition (Wood et al. 2008). Various factors, such as housing, feed composition, supplementation with natural extract and feed oil content affect lipid and fatty acid content (Gondret, 1998; Dalle Zotte and Szendrő, 2011; Vizzarri et. 2017; Enser et al. 1996). Often monitored alpha-linolenic acid is more absorbed in rabbit meat than in meat of other animal species. Acids which are the most abundant in rabbit meat are linoleic, oleic and palmitic acids (Minguez et al. 2017; Gondret, 1998). Rabbit meat is characterized by its low cholesterol content (approximately $47 \mathrm{mg} / 100 \mathrm{~g}$ ). These values are lower than those of other livestock species e.g. $62.7 \mathrm{mg} / 100 \mathrm{~g}$ in pork, $48.7 \mathrm{mg} / 100 \mathrm{~g}$ in beef, $55.3 \mathrm{mg} / 100 \mathrm{~g}$ in chickens and $52.3 \mathrm{mg} / 100 \mathrm{~g}$ in veal (Dalle Zotte, 2014). Nutrition and genotype are the most critical factors affecting the cholesterol content of meat (Kessler and Pallauf, 1995).

Zeolite is widely applied in industrial, agricultural, commercial and biomedical world due to its unique properties. The crystal structure of clinoptilolite has a 3 dimensional aluminosilicate framework, of which specific structure is a developed system of micropores and channels occupied by water molecules and exchangeable cations. The porous character of the zeolite inner surface enables the binding of neutral molecules (Koyama and Takeuchi, 1997; Bacakova et al 2018). Zeolite maintains the immune system, balances the body's $\mathrm{pH}$, reduces free radicals, neutralizes or removes harmful substances (toxins, heavy metals, nitroamines, radioactive contaminants), improves tissue oxygenation, stimulates skin regeneration and reduces blistering (Laurino, 2015). Besides, zeolite (clinoptilolite) absorbs toxins that can be dangerous to animals and eliminates mycotoxins (aflatoxins and ochratoxins) in animal feed thus reducing the mortality caused by the digestive tract diseases and along with decreased need for antibiotics (Polat et al. 2004). Natural materials as zeolite are used as alternative substitutes for plant feed supplements in poultry farming systems because of their beneficial effects on the growth and performance of broilers. The addition of zeolite to the feed has reduced overall flora in the broiler intestine and has led to improved organoleptic meat quality. There was a significant increase in the weight of broilers fed with zeolite supplemented feeding diet and also an increase in polyunsaturated fatty acid levels in chicken meat (Mallek et al. 2012) and content of saturated and unsaturated fatty acids in egg-laying hens (Fendri $\boldsymbol{e t}$ al. 2012). The zeolite has beneficial effects on pigs' performance in growth phases but did not affect the increase in body weight (Prvulovic et al. 2007).

Based on the nowadays knowledge, the production and consumption of rabbit meat in the world are negligible in comparison to other types of meat and thus also scientific work is more focused on poultry, pork, beef and poultry. The research of the effect of the zeolite (clinoptilolite) on the meat quality was already reported in chickens (Mallek et al., 2012), turkeys (Hcini et al., 2018), gees (Larina et al., 2020), pigs (Kim et al., 2014), and fish (Paritova et al., 2013). However, studies employing rabbit model for the zeolite administration focused only on the growth performance (Beshkenadze et al., 2016) or the effect on the thawed spermatozoa (Mohammed et al., 2019). The only study focused on the meat quality in terms of nutritional composition (individual amino acids and fatty acids) was realized by Chrastinova et al. (2020). Rabbits in their study were fed with diet supplemented either with zeolite or coccidiostatic drug. Obtained results of the Chrastinova et al. (2020) study reveal the safety of zeolite administration to farm breed meat and hybrid rabbits. Nevertheless, no beneficial impact of zeolite was detected either in musculus Longissimus 
thoracis or musculus lumborum. The aim of the present study was to evaluate the effect of zeolite supplementation on Castorex rabbits in domestic conditions with approach in nutritional and physico-chemical composition in musculus Longissimus dorsi and musculus Vastus lateralis.

\section{MATERIAL AND METHODS}

\section{Animals and course of experiment}

In the experiment, 12 rabbits of Castorex breed were used. Rabbits were divided into two separate groups, control group $C(n=6)$ fed with a commercial feed and experimental group $\mathrm{Z}(\mathrm{n}=6)$ fed with commercial feed and daily perorally supplemented with zeolite in form of colloid solution. Zeolite was administered in a concentration $0.2 \mathrm{~g} / \mathrm{kg}$ of body weight and dissolved in water. The doses were recalculated every week following the animal weighting. Rabbits were housed individually in single cages according to the welfare rules (EC no. $178 / 2002$ and related EC documents). Weaned rabbits at eight weeks of age were subjected to the experiment. Feed and water were available ad libitum during the whole duration of the experiment. Rabbits were bred to 20 weeks of age when they were humanely sacrificed by a slaughter spring gun followed by bleeding, skinning and evisceration. Musculus Longissimus dorsi (MLD) and the Musculus Vastus lateralis (MVL) were collected from each animal and used for further meat quality analyses.

\section{Feed composition}

Complete feed compound (CFC) contained: wheat bran, corn, hay, wheat, rapeseed meal, GMO soybean extract. Chemical composition of diet was as follows: Crude protein $(15 \%)$, Fiber $(8.8 \%)$, Oils and fats $(3.6 \%)$, Ash $(6.8 \%)$ Lysine $(0.67 \%)$, Methionine $(0.4 \%)$, Calcium ( $1 \%)$, Sodium $(0.15 \%)$, Phosphorus $(0.62 \%)$.

\section{Zeolite}

Animal feed additive ProFeed (VSK PRO - ZEO, Košice, Slovakia) was used as a zeolite supplement. Used zeolite was administered in fractions $0.0-0.200 \mathrm{~mm}$ with active substance clinoptilolite in the amount of at least $80 \%$. Dioxins were declared in a maximum of 500 pg WHO-PCDDF-TEO $/ \mathrm{kg}$. Chemical composition of ProFeed contained: $\mathrm{SiO}_{2}$ (min. $\left.62 \%\right), \mathrm{Al}_{2} \mathrm{CO}_{3}(\max 14 \%), \mathrm{Fe}_{2} \mathrm{CO}_{3}$ (max. $2.3 \%), \mathrm{CaO}(\max .5 .5 \%)$.

\section{Sample analysis}

Muscle samples (MLD and MVL) were harvested at weight at least 50 grams The following chemical parameters of rabbit meat were analyzed: protein, water, lipid, omega 3 and 6 fatty acids, cholesterol, essential and selected non-essentia amino acids, the content of selected monounsaturated fatty acids (MUFA), polyunsaturated fatty acids (PUFA), saturated fatty acids (SFA) and their total content in muscle. Determination of the nutritional composition of rabbit meat and analysis of individual amino acids and fatty acids was realized with the Nicolet 6700 by FT-IR method (Fourier transformed infrared spectroscopy). The principle of this method is the infrared absorption spectrum of the sample passes and there is a change from the rotary vibrating energy conditions of the molecule depending on the changes of the dipole moment of the molecule. The analytical output is the infrared spectrum, which is a graphical representation of the function of the energy dependence, mostly mentioned as a percentage of transmittance $(\mathrm{T})$ or in units of absorbance (A) at a wavelength of the incident radiation. Permeability is defined as the ratio of the radiation intensity which has passed through the sample (I) and of the emission intensity of emitted source (Io). Absorbance is defined as a decimal logarithm of 1/T (Angelovičová et. al. 2016) The individual analyzed parameters were processed in Microsoft Excel (descriptive statistics) and interpreted as means and expressed with SD. Obtained data were statistically analyzed using GraphPad Prism 6 (GraphPad Software, USA), employing unpaired two-tailed t-test. The statistical tests were carried out at levels of significance at $\mathrm{P}<0.05, \mathrm{P}<0.01$ and $\mathrm{P}<0.001$.

\section{RESULTS AND DISCUSSION}

Based on the results of statistical analyses, we found the following significant differences in linoleic acid content between the $\mathrm{C}$ group and the $\mathrm{Z}$ group in the MLD in favor of the $\mathrm{Z}$ group $\left(0.3243 \pm 0.016 \mathrm{~g} * 100 \mathrm{~g}^{-1} \mathrm{FAME}\right)$ compared to control group C $\left(0.2905 \pm 0.008939 \mathrm{~g} * 100 \mathrm{~g}^{-1}\right.$ FAME). Moreover, values of the cysteine content in MLD in the group $\mathrm{Z}\left(0.2898 \pm 0.007 \mathrm{~g} * 100 \mathrm{~g}^{-1}\right)$ were significantly $(\mathrm{P} \leq 0.05)$ higher than in the group $\mathrm{C}\left(0.2772 \pm 0.011 \mathrm{~g}^{*} 100 \mathrm{~g}^{-1}\right)$ The MLD muscle water content in the experimental group was $73.63 \pm 0.270 \mathrm{~g}$ * $100 \mathrm{~g}^{-1}$, which was significantly $(\mathrm{P} \leq 0.05)$ higher than in the control group $(72.48$ $\left.\pm 0.537 \mathrm{~g}^{*} 100 \mathrm{~g}^{-1}\right)$. In the MVL muscle, there were no significant differences between the control and experimental groups.

Table 1 Analyzed parameters in rabbit musculus Longissimus dorsi.

\begin{tabular}{|c|c|c|c|c|c|c|c|c|c|c|}
\hline MLD & $\mathbf{C}$ & $\mathbf{Z}$ & $\mathbf{C}$ & $\mathbf{Z}$ & $\mathbf{C}$ & $\mathbf{Z}$ & $\mathbf{C}$ & $\mathbf{Z}$ & $\mathbf{C}$ & $\mathbf{Z}$ \\
\hline & \multicolumn{2}{|c|}{$\begin{array}{l}\text { PROTEIN } \\
\left({\left.\mathrm{g} .100 \mathrm{~g}^{-1}\right)}\right.\end{array}$} & \multicolumn{2}{|c|}{$\begin{array}{c}\text { LIPID } \\
\left(\mathrm{g.100g}^{-1}\right)\end{array}$} & \multicolumn{2}{|c|}{$\begin{array}{r}\text { WATER } \\
\left(\mathrm{g.100g}^{-1}\right)\end{array}$} & \multicolumn{2}{|c|}{$\begin{array}{c}\text { CHOLESTEROL } \\
\left({\left.\mathrm{g} . \mathrm{kg}^{-1}\right)}^{-1}\right. \\
\end{array}$} & \multicolumn{2}{|c|}{$\begin{array}{c}\text { ARGININE } \\
\left({\left.\mathrm{g} .100 \mathrm{~g}^{-1}\right)}^{\text {A }}\right.\end{array}$} \\
\hline MEAN & 24.950 & 24.850 & 0.497 & 0.600 & 72.48* & 73.63* & 0.268 & 0.252 & 1.231 & 1.238 \\
\hline \multirow[t]{2}{*}{ SD } & 0.352 & 0.253 & 0.098 & 0.103 & 0.537 & 0.270 & 0.044 & 0.021 & 0.046 & 0.037 \\
\hline & \multicolumn{2}{|c|}{$\begin{array}{l}\text { CYSTEINE } \\
\left(\mathrm{g.100g}^{-1}\right)\end{array}$} & \multicolumn{2}{|c|}{$\begin{array}{c}\text { PHENYLALANINE } \\
\left({\left.\mathrm{g} .100 \mathrm{~g}^{-1}\right)}^{\text {PHIN }}\right.\end{array}$} & \multicolumn{2}{|c|}{$\begin{array}{c}\text { HISTIDINE } \\
\left(\mathrm{g.100 \textrm {g } ^ { - 1 } )}\right. \\
\end{array}$} & \multicolumn{2}{|c|}{$\begin{array}{c}\text { ISOLEUCINE } \\
\left(\mathrm{g.100g}^{-1}\right)\end{array}$} & \multicolumn{2}{|c|}{$\begin{array}{c}\text { LEUCINE } \\
\left(\mathrm{g} .100 \mathrm{~g}^{-1}\right) \\
\end{array}$} \\
\hline MEAN & $0.2772 *$ & 0.2898* & 0.802 & 0.807 & 0.801 & 0.818 & 0.746 & 0.753 & 1.546 & 1.563 \\
\hline \multirow[t]{2}{*}{ SD } & 0.011 & 0.007 & 0.029 & 0.019 & 0.049 & 0.018 & 0.029 & 0.026 & 0.055 & 0.045 \\
\hline & \multicolumn{2}{|c|}{$\begin{array}{l}\text { LYSINE } \\
\left(\mathrm{g.100g}^{-1}\right)\end{array}$} & \multicolumn{2}{|c|}{ 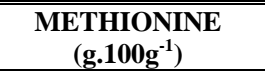 } & \multicolumn{2}{|c|}{$\begin{array}{l}\text { THREONINE } \\
\left({\left.\mathrm{g} .100 \mathrm{~g}^{-1}\right)}\right.\end{array}$} & \multicolumn{2}{|c|}{$\begin{array}{l}\text { VALINE } \\
\left(\mathrm{g.100g}^{-1}\right) \\
\end{array}$} & \multicolumn{2}{|c|}{$\begin{array}{c}\text { MUFA } \\
\left(\text { g.100g }{ }^{-1} \text { FAME) }\right.\end{array}$} \\
\hline MEAN & 1.642 & 1.652 & 0.602 & 0.611 & 0.902 & 0.934 & 0.873 & 0.883 & 48.040 & 48.450 \\
\hline \multirow[t]{2}{*}{ SD } & 0.063 & 0.048 & 0.020 & 0.012 & 0.026 & 0.029 & 0.028 & 0.021 & 1.623 & 0.913 \\
\hline & \multicolumn{2}{|c|}{$\begin{array}{c}\text { PUFA } \\
\left(\text { g.100g }{ }^{-1} \text { FAME }\right)\end{array}$} & \multicolumn{2}{|c|}{$\begin{array}{c}\text { SFA } \\
\left(\text { g.100g }{ }^{-1} \text { FAME }\right)\end{array}$} & \multicolumn{2}{|c|}{$\begin{array}{c}\text { OMEGA 3 } \\
\left(\text { g.100g }{ }^{-1} \text { FAME) }\right.\end{array}$} & \multicolumn{2}{|c|}{$\begin{array}{c}\text { OMEGA 6 } \\
\left(\text { g.100g }{ }^{-1} \text { FAME) }\right.\end{array}$} & \multicolumn{2}{|c|}{$\begin{array}{l}\text { ESENTIAL FA } \\
\left(\text { g.100g }^{-1} \text { FAME) }\right.\end{array}$} \\
\hline MEAN & 11.920 & 11.100 & 36.300 & 35.800 & 0.553 & 0.562 & 10.820 & 10.330 & 9.522 & 9.405 \\
\hline \multirow[t]{2}{*}{ SD } & 0.739 & 0.585 & 0.914 & 0.900 & 0.054 & 0.034 & 0.408 & 0.360 & 1.052 & 1.071 \\
\hline & \multicolumn{2}{|c|}{$\begin{array}{c}\text { HEPTADECANOID A. } \\
\left({\left.\mathrm{g} .100 \mathrm{~g}^{-1} \text { FAME }\right)}^{-}\right.\end{array}$} & \multicolumn{2}{|c|}{$\begin{array}{c}\text { LAURIC A. } \\
\left(\text { g.100g }^{-1} \text { FAME) }\right.\end{array}$} & \multicolumn{2}{|c|}{$\begin{array}{c}\text { MYRISTIC A. } \\
\text { (g.100g }{ }^{-1} \text { FAME) }\end{array}$} & \multicolumn{2}{|c|}{$\begin{array}{c}\text { PALMIT A. } \\
\left(\text { g.100g }^{-1} \text { FAME) }\right.\end{array}$} & \multicolumn{2}{|c|}{$\begin{array}{c}\text { STEARIC A. } \\
\left(\text { g.100g }^{-1} \text { FAME) }\right.\end{array}$} \\
\hline MEAN & 0.336 & 0.348 & 0.059 & 0.056 & 1.349 & 1.321 & 24.370 & 24.410 & 10.700 & 10.780 \\
\hline \multirow[t]{2}{*}{ SD } & 0.021 & 0.035 & 0.003 & 0.004 & 0.017 & 0.035 & 0.150 & 0.180 & 0.295 & 0.216 \\
\hline & \multicolumn{2}{|c|}{ 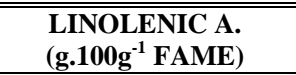 } & \multicolumn{2}{|c|}{$\begin{array}{l}\text { LINOLEIC A. } \\
\left(\text { g.100g }^{-1} \text { FAME) }\right.\end{array}$} & \multicolumn{2}{|c|}{$\begin{array}{c}\text { OLEIC A. } \\
\left(\text { g.100g }{ }^{-1} \text { FAME }\right)\end{array}$} & (g.100 & & $\begin{array}{r}\text { VAK } \\
\text { (g.100g } \\
\end{array}$ & AE) \\
\hline MEAN & 0.2905* & 0.3243* & 0.051 & 0.050 & 39.550 & 41.940 & 0.142 & 0.141 & 4.851 & 4.806 \\
\hline SD & 0.009 & 0.016 & 0.001 & 0.001 & 2.512 & 1.674 & 0.008 & 0.009 & 0.062 & 0.088 \\
\hline & (g.100 & $\begin{array}{l}\text { A } \\
\text { FAM) }\end{array}$ & $\begin{array}{r}A \\
(g .100 g \\
\end{array}$ & ME) & $\begin{array}{r}\mathrm{E} \\
(\mathrm{g.100g} \\
\end{array}$ & IE) & & & & \\
\hline MEAN & 0.036 & 0.037 & 1.913 & 1.898 & 0.120 & 0.122 & & & & \\
\hline SD & 0.004 & 0.004 & 0.278 & 0.275 & 0.011 & 0.010 & & & & \\
\hline
\end{tabular}

Legend: $\mathrm{C}$ - control group, $\mathrm{Z}$ - experimental Zeolite group. Significant difference: * P $\leq 0.05, \mathrm{~A}-$ acid, FA - fatty acid, FAME - fatty acid methyl ester, CLA - conjugated linoleic acid, DHA - docosahexaenoic acid, ARA - arachidonic acid, EPA - eicosapentaenoic acid, SD - standard deviation. 
Table 2 Analyzed parameters in rabbit musculus Vastus lateralis

\begin{tabular}{|c|c|c|c|c|c|c|c|c|c|c|}
\hline MVL & C & $\mathbf{Z}$ & C & $\mathbf{Z}$ & C & $\mathbf{Z}$ & C & $\mathbf{Z}$ & C & $\mathbf{Z}$ \\
\hline & \multicolumn{2}{|c|}{$\begin{array}{c}\text { PROTEIN } \\
\left({\left.\text { g. } 100 g^{-1}\right)}^{\text {Pat }}\right. \\
\end{array}$} & \multicolumn{2}{|c|}{$\begin{array}{c}\text { LIPID } \\
\left(\mathrm{g.100g^{-1 }}\right)\end{array}$} & \multicolumn{2}{|c|}{$\begin{array}{c}\text { WATER } \\
\left(\mathrm{g} .100 \mathrm{~g}^{-1}\right) \\
\end{array}$} & \multicolumn{2}{|c|}{$\begin{array}{c}\text { CHOLESTEROL } \\
\left(\mathrm{g} . \mathrm{kg}^{-1}\right)\end{array}$} & \multicolumn{2}{|c|}{$\begin{array}{c}\text { ARGININE } \\
\left({\left.\mathrm{g} .100 \mathrm{~g}^{-1}\right)}^{-1}\right.\end{array}$} \\
\hline MEAN & 23.860 & 24.010 & 0.842 & 0.832 & 72.760 & 72.970 & 0.338 & 0.295 & 1.273 & 1.272 \\
\hline \multirow[t]{2}{*}{ SD } & 0.341 & 0.209 & 0.142 & 0.136 & 0.464 & 0.424 & 0.063 & 0.055 & 0.042 & 0.098 \\
\hline & \multicolumn{2}{|c|}{$\begin{array}{c}\text { CYSTEINE } \\
\left(\mathrm{g} .100 \mathrm{~g}^{-1}\right)\end{array}$} & \multicolumn{2}{|c|}{$\begin{array}{c}\text { PHENYLALANINE } \\
\left(\mathrm{g}^{\circ} 100 \mathrm{~g}^{-1}\right)\end{array}$} & \multicolumn{2}{|c|}{$\begin{array}{c}\text { HISTIDINE } \\
\left(\mathrm{g} .100 \mathrm{~g}^{-1}\right)\end{array}$} & \multicolumn{2}{|c|}{$\begin{array}{c}\text { ISOLEUCINE } \\
\left(\mathrm{g} .100 \mathrm{~g}^{-1}\right)\end{array}$} & \multicolumn{2}{|c|}{$\begin{array}{c}\text { LEUCINE } \\
\left(\mathrm{g.100g}^{-1}\right)\end{array}$} \\
\hline MEAN & 0.282 & 0.280 & 0.832 & 0.828 & 0.870 & 0.849 & 0.776 & 0.776 & 1.601 & 1.599 \\
\hline \multirow[t]{2}{*}{ SD } & 0.014 & 0.010 & 0.023 & 0.057 & 0.042 & 0.047 & 0.031 & 0.060 & 0.051 & 0.109 \\
\hline & \multicolumn{2}{|c|}{$\begin{array}{c}\text { LYSINE } \\
\left(\text { g.100g }^{-1}\right)\end{array}$} & \multicolumn{2}{|c|}{$\begin{array}{c}\text { METHIONINE } \\
\left({\left.\mathrm{g} .100 \mathrm{~g}^{-1}\right)}^{-1}\right.\end{array}$} & \multicolumn{2}{|c|}{$\begin{array}{c}\text { THREONINE } \\
\left(\mathrm{g} .100 \mathrm{~g}^{-1}\right)\end{array}$} & \multicolumn{2}{|c|}{$\begin{array}{l}\text { VALINE } \\
(\text { g.100g } \\
-1)\end{array}$} & \multicolumn{2}{|c|}{$\begin{array}{c}\text { MUFA } \\
\left(\mathrm{g} .100 \mathrm{~g}^{-1} \text { FAME) }\right.\end{array}$} \\
\hline MEAN & 1.703 & 1.699 & 0.625 & 0.616 & 0.923 & 0.928 & 0.908 & 0.903 & 49.810 & 49.63 \\
\hline \multirow[t]{2}{*}{ SD } & 0.055 & 0.130 & 0.024 & 0.039 & 0.031 & 0.044 & 0.019 & 0.041 & 0.413 & 0.6106 \\
\hline & \multicolumn{2}{|c|}{$\begin{array}{c}\text { PUFA } \\
\left(\mathrm{g} .100 \mathrm{~g}^{-1} \text { FAME }\right)\end{array}$} & \multicolumn{2}{|c|}{$\begin{array}{c}\text { SFA } \\
\left(\mathrm{g} .100 \mathrm{~g}^{-1} \text { FAME }\right)\end{array}$} & \multicolumn{2}{|c|}{$\begin{array}{c}\text { OMEGA 3 } \\
\left(\mathrm{g.100 \textrm {g } ^ { - 1 }} \text { FAME) }\right.\end{array}$} & \multicolumn{2}{|c|}{$\begin{array}{c}\text { OMEGA 6 } \\
\left(\mathrm{g.100g}^{-1} \text { FAME) }\right.\end{array}$} & \multicolumn{2}{|c|}{$\begin{array}{l}\text { ESENTIAL FA } \\
\left(\mathrm{g.100g}^{-1} \text { FAME) }\right.\end{array}$} \\
\hline MEAN & 10.560 & 10.530 & 35.910 & 35.400 & 0.530 & 0.565 & 9.927 & 9.695 & 9.503 & 9.615 \\
\hline \multirow[t]{2}{*}{ SD } & 0.547 & 1.020 & 0.999 & 1.024 & 0.057 & 0.036 & 0.249 & 0.581 & 0.560 & 0.941 \\
\hline & \multicolumn{2}{|c|}{$\begin{array}{c}\text { HEPTADECANOID A. } \\
\left(\mathrm{g} .100 \mathrm{~g}^{-1} \text { FAME) }\right.\end{array}$} & \multicolumn{2}{|c|}{ 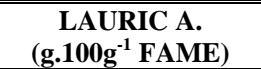 } & \multicolumn{2}{|c|}{$\begin{array}{c}\text { MYRISTIC A. } \\
\text { (g.100g }{ }^{-1} \text { FAME) } \\
\end{array}$} & \multicolumn{2}{|c|}{$\begin{array}{c}\text { PALMIT A. } \\
\left(\text { g.100g }^{-1} \text { FAME }\right)\end{array}$} & \multicolumn{2}{|c|}{$\begin{array}{c}\text { STEARIC A. } \\
\left(\mathrm{g} .100 \mathrm{~g}^{-1} \text { FAME }\right)\end{array}$} \\
\hline MEAN & 0.340 & 0.330 & 0.061 & 0.059 & 1.332 & 1.328 & 24.360 & 24.490 & 10.670 & 10.850 \\
\hline \multirow[t]{2}{*}{ SD } & 0.019 & 0.036 & 0.005 & 0.004 & 0.019 & 0.032 & 0.189 & 0.197 & 0.263 & 0.143 \\
\hline & \multicolumn{2}{|c|}{$\begin{array}{c}\text { LINOLENIC A } \\
\left(\mathrm{g.100g}^{-1} \text { FAME) }\right.\end{array}$} & \multicolumn{2}{|c|}{$\begin{array}{c}\text { LINOLEIC A. } \\
\left(\mathrm{g.100g}^{-1} \text { FAME) }\right.\end{array}$} & \multicolumn{2}{|c|}{$\begin{array}{c}\text { OLEIC A. } \\
\left(\mathrm{g} .100 \mathrm{~g}^{-1} \text { FAME) }\right.\end{array}$} & (g.10 & ME) & $\begin{array}{r}\text { VAF } \\
\text { (g.100 } \\
\end{array}$ & $\begin{array}{l}\text { A. } \\
\text { ME) }\end{array}$ \\
\hline MEAN & 0.288 & 0.309 & 0.051 & 0.051 & 40.660 & 40.110 & 0.141 & 0.142 & 4.823 & 4.825 \\
\hline SD & 0.026 & 0.022 & 0.002 & 0.001 & 1.819 & 2.966 & 0.004 & 0.009 & 0.087 & 0.063 \\
\hline & (g.10 & AME) & (g.10 & ME) & (g.10) & AME) & & & & \\
\hline MEAN & 0.037 & 0.037 & 1.899 & 1.839 & 0.122 & 0.120 & & & & \\
\hline SD & 0.004 & 0.004 & 0.143 & 0.284 & 0.007 & 0.012 & & & & \\
\hline
\end{tabular}

Legend: C - control group, Z - experimental Zeolite group. A - acid, MUFA - mono-unsaturated fatty acid, SFA - saturated fatty acid, PUFA - polyunsaturated fatty acid, FAME - fatty acid methyl ester, CLA - conjugated linoleic acid, DHA - docosahexaenoic acid, ARA - arachidonic acid, EPA eicosapentaenoic acid, SD - standard deviation.

Zeolites, mineral rocks of volcanic origin, are chemically hydrated alkali metal alumosilicates and alkaline earth metals. The biological effects of the natural zeolite, such as adsorption, cation exchange, and catalytic properties, are related to its unique structural characteristics, which are known as molecular sieves. Natural zeolite is currently used in various technological processes such as water purification, soil structure improvement, pond cleaning, radioprotection, food supplement, and feed mixture additive. The zeolite in an animal's digestive tract is relatively stable and can absorb heavy metals, free radicals, and toxins in the body and afterward excrete them. The administration of zeolite as a feed supplement potentially enhance feed utilization (Dalle Zotte, 2002; Bacakova et al. 2019).

The previous study (Beshkenadze et al. 2016) on the rabbit showed that the addition of a mixture of zeolite and chelated microelement ( $\mathrm{Mn}, \mathrm{Zn}, \mathrm{Fe}, \mathrm{Co}, \mathrm{Cu}$ ) to the animal diet has a positive effect on the health of rabbits, improves feed assimilation in digestive tract and accelerates growth. In our study, we did not record an increase in body weight gain (data not showed). Since the Californian and Gray giant rabbits are broiler breeds intended for meat production and the Castorex breed belongs among fur breeds, it is difficult to compare increments and feed assimilation between these studies. Such a comparison might have been unreliable. Californian and Gray giant rabbit breeds have a different productive purpose than the Castorex breed and they also have a different genotype.

Due to a lack of previous studies and information, it is necessary to take into consideration the effect of zeolite on selected parameters of meat of other animal species. Results of Beshkenadze et al. (2016) partially follow the studies of Safaei et al. (2012) who examined the effect of zeolite on other animal species. In their work, they investigated the effect of zeolite on broiler chickens, where they similarly found a better weight gain in experimental animals. Zeolite concentrations of $1 \%$ and $3 \%$ of the total feed ration was added to the feed mixture. Statistically significant $(\mathrm{P} \leq 0.05)$ weight gain was recorded after the administration of both concentrations of zeolite (1.5 and $3 \%)$ compared to control. In contrast, Wu et al. (2013) reported no significant effect of natural clinoptilolite (NCLI) and modified clinoptilolite (MCLI) on broiler performance. Birds in the control group received a basal diet, while in the experimental groups the broilers were fed with basic feeding ration supplemented with $2 \%$ NCLI and $2 \%$ MCLI for 42 days. The results showed that compared to the control, the feed supplemented with NCLI or MCLI did not result in significant $(\mathrm{P} \geq 0.05)$ effects on productive parameters. Furthermore, in this study, authors indicate that the efficacy of zeolites may vary due to factors such as origin, purity, concentration, fraction size, clinoptilolite content in the zeolite, diet composition and content The effects of zeolite (clinoptilolite) in pig nutrition have been investigated by Prvulovic et al $\mathbf{( 2 0 0 7 )}$ in sixty Landrace $\times$ Yorkshire pigs. During the first 45 and 90 days of the experiment, $\mathrm{Cp}$ pigs had higher body weight gains compared to the control group $(+2.5 \%$ and $+7.0 \%$ respectively), but the experimental group lagged behind the control on average at the end of the experiment $(-4.8 \%)$ In our study, we also did not observe a significant $(\mathrm{P} \leq 0.05)$ difference in the body weight gain of the experimental group to the control group. Weight gain in experimental group $\mathrm{Z}$ in our study was decreased by $0.68 \%$.

Mallek et al. (2012) report that the linolenic and linoleic acid content were rapidly $(\mathrm{P}<0.01)$ elevated in chickens of zeolite-treated group compared to control group These variations in unsaturated fatty acids contribute to an overall decrease in saturated fatty acid values in the experimental groups. This does not correspond with our study where we did not find any significant difference in the linoleic acid content of MLD and MVL, which could be due to a different concentration of zeolite administered, a percentage of lipids in CFC, fewer animals in our experiments or other animal species to which the zeolite may not have the same effects. Adding $0.2 \mathrm{~g}$ of zeolite per $\mathrm{kg}$ of live weight to the basic rabbit feeding dose resulted in an enhanced $(\mathrm{P} \leq 0.05)$ level of linolenic acid in MLD. Along with a higher concentration of linoleic acid $(\mathrm{P} \leq 0.05)$, we detected no other significant differences between control and experimental groups.

The use of natural zeolites in animal production was investigated by Burmańczuk et al. (2015). As a result, the average weight gain in 5\%-zeolite group was reported being statistically significant $(\mathrm{P}>0.05)$ higher compared with control group. The positive effect of dietary supplementation of zeolite on fatty acids profile was reported also in context with chicken eggs. Fendri et al. (2012) focused on the addition of $1 \%$ and $2 \%$ of zeolite to the compound feeds and examined the quality of the eggs after the addition of the zeolite. Another study showed how the addition of $15 \mathrm{~g}$ and $30 \mathrm{~g}$ of kaolin, bentonite, and zeolite per $\mathrm{kg}$ of feed affect the quality of broiler chickens (Safaei et al. (2016). Claimed results prove that these minerals increase oxidative stability and meat storage time in addition to reducing rancidity over storage time and indicate that silicate minerals as an effective feed additive preserve the quality of broiler meat after slaughter and during storage. However, the determination of the direct effect of zeolites on the quality of the meat requires more thorough studies. Chrastinova et al. (2020) administrated rabbits with zeolite in amount of $1 \%$ of the feeding ration and observed nutritional and physico-chemical composition of musculus longissimus thoracis and musculus lombarum. However, no significant differences were detected compared to control. The present study recorded significant increase of water in the musculus Longissimus dorsi as well as elevated levels of cysteine and linolenic acid, nonetheless, no statistical difference was found between control and treated group in musculus Vastus lateralis.

Detected changes in chemical composition of rabbit meat may refer to positive biological activity of zeolite. Well known detoxifying effects are accompanied 
with strong antioxidant activity. Even though antioxidant capacity of zeolite is still not clear, it is assumed that zeolite offers metal ions (e.g. Ca, Mn, $\mathrm{Zn}$ and $\mathrm{Mg}$ ) within its structure for the activation of antioxidant enzymes. The application of zeolite is scientifically associated with increased activity of catalase, GSH and SOD enzymes (Mastinu et al.2019; Kraljevic Pavelic et al. 2018

\section{CONCLUSION}

In our work, we described and evaluated the effect of zeolite, as a feed additive in rabbit feeding ration, on selected chemical parameters of rabbit meat. In the case of MVL chemical analyses, there were no significant differences between the observed groups. The results of our work show that after the administration of zeolite (clinoptilolite), the linolenic acid content of the dorsal muscle (MLD) of rabbits increased significantly, which has a positive effect on the nutritional value of the meat. However, it is necessary to examine how this increase in linolenic acid will affect the oxidative stability of the meat throughout the storage. An increased cysteine content in the $\mathrm{Z}$ group has also been detected in the MLD, which may help to break down heavy metals from the body as well as from the meat as it is known that the amino acids in the organism acts also as part of the detoxification system.

Acknowledgments: This work was supported by projects 12-GASPU-2018, KEGA 034SPU-4/2019, APVV-16-0289 and by the Operational program Integrated Infrastructure within the project: Demand-driven research for the sustainable and innovative food, Drive4SIFood 313011V336, cofinanced by the European Regional Development Fund.

\section{REFERENCES}

Angelovičová, M., Mellen, M., Bučko, O., Tkáčová, J., Čapla, J., Zajác, P., Angelovič, M. (2016). Relation between selected nutrients in the chicken meat depending on phytogenic feed additives. Potravinárstvo, 10(1), 215-222. https://doi.org/10.5219/573

Bacakova, L., Vandrovcova, M., Kopova, I., \& Jirka, I. (2018). Applications of zeolites in biotechnology and medicine-a review. Biomaterials science, 6(5), 974-989. https://doi.org/10.1039/C8BM00028J

Beshkenadze, I., Chagelishvili, A., Begheluri, G., Zhorzholiani, N., Gogaladze, M., Urotadze, S., \& Klarjeishvili, N. (2016). New generation premixes for rabbit nutrition. Annals of Agrarian Science, 14(4), 288-291. https://doi.org/10.1016/j.aasci.2016.06.001

Burmanczuk, A., Rolinski, Z., Kowalski, C., Burmanczuk, N., \& Markiewicz, W. (2015). Possible use of natural zeolites in animal production and environment protection. Journal of Elementology, 20(4). 803-811. https://doi.org/10.5601/jelem.2014.19.4.759

Dalle Zotte, A. (2002). Perception of rabbit meat quality and major factors influencing the rabbit carcass and meat quality. Livestock production science, 75(1), 11-32. https://doi.org/10.1016/S0301-6226(01)00308-6

Dalle Zotte, A. (2014). Rabbit farming for meat purposes. Animal Frontiers, 4(4), 62-67. https://doi.org/10.2527/af.2014-0035

Dalle Zotte, A., \& Szendrö, Z. (2011). The role of rabbit meat as functional food. Meat science, 88(3), 319-331. https://doi.org/10.1016/j.meatsci.2011.02.017

Enser, M., Hallett, K., Hewitt, B., Fursey, G. A. J., \& Wood, J. D. (1996). Fatty acid content and composition of English beef, lamb and pork at retail. Meat Science, 42(4), 443-456. https://doi.org/10.1016/0309-1740(95)00037-2

Fendri, I., Khannous, L., Mallek, Z., Traore, A. I., Gharsallah, N., \& Gdoura, R. (2012). Influence of Zeolite on fatty acid composition and egg quality in Tunisian Laying Hens. Lipids in health and disease, 11(1), 71 http://doi.org/10.1186/1476-511X-11-71

Gondret, F., Juin, H., Mourot, J., \& Bonneau, M. (1998). Effect of age at slaughter on chemical traits and sensory quality of Longissimus lumborum muscle in the rabbit. Meat science, 48(1-2), 181-187. https://doi.org/10.1016/S0309-1740(97)00088-0

Hernández, P. (2007). Carne de conejo, ideal para dietas bajas en ácido úrico. Rev. Científica de Nutrición (154), 33-36.

Hcini, E., Ben Slima, A., Kallel, I., Zormati, S., Traore, A. I., \& Gdoura, R. (2018). Does supplemental zeolite (clinoptilolite) affect growth performance, meat texture, oxidative stress and production of polyunsaturated fatty acid of Turkey poults? Lipids in Health and Disease, 17(1). https://doi.org/10.1186/s12944-018-0820-7

Chrastinova, L., Chrenkova, M., Formelova, Z., Laukova, A., Simonova, M. P., Rajsky, M., ... \& Jurcik, R. (2020). Use of enterocin M substance applied in drinking water and natural zeolite as dietary supplements for growing rabbits. Slovak Journal of Animal Science, 53(01), 12-18.

Kessler, B., \& Pallauf, J. (1994). Fatty acid composition and cholesterol content of the musculus longissimus dorsi of meat rabbits fed oil from coconut, rape or soybean. Zuechtungskunde (Germany).

Kim, C.-B., Yang, C.-J., Choi, O. J., Jung, H. N., \& Shim, K. H. (2014). Effect of Dietary Supplementation of Zeolite on the Quality of Pork Shoulder Before and
After Cooking. Korean Journal of Food and Cookery Science, 30(2), 193-199. https://doi.org/10.9724/kfcs.2014.30.2.193

Koyama, K., \& Takeuchi, Y. (1977). Clinoptilolite: the distribution of potassium atoms and its role in thermal stability. Zeitschrift für Kristallographie-Crystalline Materials, 145(1-6), 216-239. https://doi.org/10.1524/zkri.1977.145.16.216

Kraljević Pavelić, S., Simović Medica, J., Gumbarević, D., Filošević, A., Pržulj, N., \& Pavelić, K. (2018). Critical review on zeolite clinoptilolite safety and medical applications in vivo. Frontiers in Pharmacology, 9, 1350 https://doi.org/10.3389/fphar.2018.01350

Larina, Y., Ezhkov, V., Fayzrakhmanov, R., \& Ezhkova, A. (2020). Mea productivity and quality of goose meat when using nanostructural zeolite in $\begin{array}{lllll}\text { feeding. } & \mathrm{BIO} & \mathrm{Web} \text { of } & & \end{array}$ https://doi.org/10.1051/bioconf/20202700028

Laurino, C., Palmieri, B. (2015). Zeolite: "The magic stone"; main nutritional, environmental, experimental and clinical fields of application. Nutricion hospitalaria, 32(2), 573-581. https://doi.org/10.3305/nh.2015.32.2.8914

Mallek, Z., Fendri, I., Khannous, L., Hassena, A. B., Traore, A. I., Ayadi, M. A., \& Gdoura, R. (2012). Effect of zeolite (clinoptilolite) as feed additive in Tunisian broilers on the total flora, meat texture and the production of omega 3 polyunsaturated fatty acid. Lipids in health and disease, 11(1), 35 http://doi.org/10.1186/1476-511X-11-35

Mastinu, A., Kumar, A., Maccarinelli, G., Bonini, S. A., Premoli, M., Aria, F., Gianoncelli, A., \& Memo, M. (2019). Zeolite Clinoptilolite: Therapeutic Virtues of an Ancient Mineral. Molecules (Basel, Switzerland), 24(8), 1517 https://doi.org/10.3390/molecules24081517

Mínguez, C., Sánchez, J. P., Hernández, P., Ragab, M., Nagar, A. E., \& Baselga, M. (2017). Genetic analysis of meat quality traits in maternal lines of rabbit and their diallel cross. Meat science, 131, 1-8 https://doi.org/10.1016/j.meatsci.2017.04.005

Mohammed, A., Khalil, W., Gabr, S., Hammad, M., Youssef, H., \& Mehrez, A. (2019). Impact of Zeolite Addition in Semen Extender on Rabbit Sperm Quality after Cryopreservation. Journal of Animal and Poultry Production, 10(10), 317322. https://doi.org/10.21608/jappmu.2019.63457

Nagao, T., Komine, Y., Soga, S., Meguro, S., Hase, T., Tanaka, Y., \& Tokimitsu, I. (2005). Ingestion of a tea rich in catechins leads to a reduction in body fat and malondialdehyde-modified LDL in men. The American journal of clinical nutrition, 81(1), 122-129. https://doi.org/10.1093/ajen/81.1.122

Paritova, A. (2014). The Influence of Chankanay Zeolites as Feed Additives on the Chemical, Biochemical and Histological Profile of the Rainbow Trout (Oncorhynchus mykiss). Journal of Aquaculture Research \& Development, 05(01). https://doi.org/10.4172/2155-9546.1000205

Polat, E., Karaca, M., Demir, H., \& Onus, A. N. (2004). Use of natural zeolite (clinoptilolite) in agriculture. Journal of fruit and ornamental plant research, 12(1), 183-189.

Prvulović, D., Jovanović-Galović, A., Stanić, B., Popović, M., \& Grubor-Lajšić, G. (2007). Effects of a clinoptilolite supplement in pig diets on performance and serum parameters. Czech Journal of Animal Sciences, 52(6), 159-66. https://doi.org/10.17221/2317-CJAS

Safaeikatouli, M., Boldaji, F., Dastar, B., \& Hassani, S. (2012). Growth response and tibia bone characteristics in broilers fed diets containing kaolin, bentonite and zeolite. Journal of Animal and Feed Sciences, 21(2). https://doi.org/10.22358/jafs/66085/2012

Safaei, M., Rezaei, R., Boldaji, F., Dastar, B., Taran, M., \& Hassani, S. (2016) The effects of kaolin, bentonite and zeolite dietary supplementation on broiler chickens meat quality during storage. Veterinary Science Development, 6(1) https://doi.org/10.4081/vsd.2016.6156

Vizzarri, F., Palazzo, M., D’Alessandro, A. G., \& Casamassima, D. (2017). Productive performance and meat quality traits in growing rabbit following the dietary supplementation of Lippia citriodora, Raphanus sativus and Solanum $\begin{array}{llll}\text { lycopersicum } \quad \text { extracts. } & \text { Livestock } & \text { Science, 59. }\end{array}$ https://doi.org/10.1016/j.livsci.2017.04.007

Wood, J. D., Enser, M., Fisher, A. V., Nute, G. R., Sheard, P. R., Richardson, R. I., .. \& Whittington, F. M. (2008). Fat deposition, fatty acid composition and meat quality: A review. Meat science, 78(4), 343-358. https://doi.org/10.1016/j.meatsci.2007.07.019

Wu, Q. J., Wang, L. C., Zhou, Y. M., Zhang, J. F., \& Wang, T. (2013). Effects of clinoptilolite and modified clinoptilolite on the growth performance, intestina microflora, and gut parameters of broilers. Poultry Science, 92(3), 684-692. https://doi.org/10.3382/ps.2012-02308 